\title{
Use of Antipsychotic Long-acting Injection in Ekbom Syndrome: A Case of Delusional Parasitosis
}

\section{Ekbom Sendromunda Uzun Etkili Antipsikotik Enjeksiyon Kullanımı: Bir Delüzyonel Parazitoz Olgusu}

\author{
(i) Elvan ÇİÇEKÇí1 ${ }^{1}$, ${ }^{0}$ Mehmet Hamdi ÖRÜM ${ }^{1}$
}

${ }^{1}$ Kahta State Hospital, Clinic of Psychiatry, Adiyaman, Turkey

\begin{abstract}
Ekbom syndrome is the clinical term for delusional parasitosis and is characterized by the patient's fixed and false conviction of being infested with parasites without any objective evidence. Patients with Ekbom syndrome often consult dermatologists, however, sometimes they might try to heal themselves by "removing" the parasites, which may lead to a skin-picking disorder or excoriation. The patient's obsessive treatment of such skin lesions ultimately leads to a vicious cycle that further distances them from psychiatry. Patients with poor adherence to psychiatric treatment may become chronic if left untreated. Although the benefit of antipsychotics in Ekbom syndrome is well-known, a chronic patient who has insufficient social support is not expected to comply with oral therapy. Antipsychotic long-acting injection should be considered as an option for such patients. In this case report, we present a male patient with delusional disorder who showed a symptomatic improvement after being treated with antipsychotic long-acting injection.
\end{abstract}

Keywords: Ekbom syndrome, delusional infestation, delusional parasitosis, delusional disorder, antipsychotic long-acting injection

\section{ÖZ}

Klinikte delüzyonel parazitoz olarak adlandırılan Ekbom sendromu, herhangi bir nesnel kanıt olmadan parazitlerle enfekte olduğu sabit ve yanlış öznel inancı ile karakterizedir. Ekbom sendromlu hastalar sıklıkla dermatologlara başvururlar ve bazen ekskoriyasyona neden olabilecek parazitleri "kazıyarak" kendilerini iyileştirmeye çalışırlar. Bu deri lezyonlarının zorunlu tedavisi, nihayetinde hastayı psikiyatriden uzaklaştıran kısır bir döngüye neden olur. Zaten psikiyatrik tedaviye uyumu zayıf olan bu hastalar, tedavi edilmezse hastalık kronik hale gelebilir. Ekbom sendromunda antipsikotiklerin yararı bilinmesine rağmen, kronik olan ve sosyal desteği yetersiz olan bir hastanın oral tedaviye uyum sağlayacağı beklenmemektedir. Antipsikotik uzun etkili enjeksiyon bu hastalarda bir seçenek olarak düşünülmelidir. $\mathrm{Bu}$ olgu sunumunda, antipsikotik uzun etkili enjeksiyon tedavisi ile semptomatik iyileşme gösteren delüzyonel bozukluğu olan bir erkek hasta sunuyoruz.

Anahtar Sözcükler: Ekbom sendromu, delüzyonel infestasyon, delüzyonel parazitoz, delüzyonel bozukluk, antipsikotik uzun etkili enjeksiyon

\section{Introduction}

Delusional parasitosis, also known as Ekbom syndrome, is a rare psychiatric disorder, generally affecting women and more commonly seen among married individuals. A person with this syndrome has a false and constant belief that their body is infested

by parasites or insects, and this delusion continues even when no medical evidence of parasites or insects is found in the patient's body $(1,2)$. The patients often report experiencing an itch-like sensation that binds to their delusion of the presence of parasites under or inside their skin. Some patients even try to heal their

Address for Correspondence: Mehmet Hamdi ÖRÜM, Kahta State Hospital, Clinic of Psychiatry, Adiyaman, Turkey

E-mail: mhorum@hotmail.com ORCID ID: orcid.org/0000-0002-4154-0738 
skin by scraping it off using disinfectants and pesticides (1). This causes a vicious cycle of skin lesions, itching and delusional belief among the patients. The lesions are often found on the trunk and scalp (2) of the patient, and it is because of the lesions that the patients are often referred to dermatologists. When referred to a psychiatrist, most patients are hopeless and convinced that the psychiatrists are incompetent and cannot provide the right treatment. They are usually angry and stressed about it. A large number of patients refuse to see a psychiatrist in any way, and like any paranoid patient, they are meticulous, demanding, disturbing and arrogant. The story often reverts to the physical symptoms and so the patients either refuse to take the treatment or do not comply with it (3). Delusional parasitosis has been classified as "delusional disorder, somatic subtype" in the Diagnostic and Statistical Manual of Mental Disorders, $5^{\text {th }}$ Edition (DSM-5) (4). It can be classified as primary and secondary etiologically. Although the diagnostic criteria of Ekbom syndrome have been defined, there is no consensus on its treatment. The opinion that treating the disease as a classical delusional disorder and treating it is common (2). In this case report, we discuss the recovery process of antipsychotic long-acting injections in a patient with Ekbom syndrome who developed various skin-related complications but refused oral antipsychotic treatment.

\section{Case Report}

A 75-year-old male patient was referred to our psychiatry clinic with the suspicion of psychotic symptoms by a dermatologist accompanied by social workers. The patient had consulted various dermatologists for over a course of approximately 20 years with the complaint of lice, Pediculus humanus, in his hair. Although the patient did not have any skin problems, he had used many different lice medications for many years. However, nothing ever worked for him and he eventually decided go bald. Nevertheless, when his hair began to regrow, he assumed them to be lice coming out of his head and started constantly dealing with his scalp. As a result, many lesions appeared on the patient's scalp. He finally consulted dermatologists to treat those lesions. When he started receiving the treatment, he went back to thinking that he has lice in his head and the doctors finally agreed. Every time he was referred to the psychiatrist to break this vicious cycle, he reacted with anger. The patient was and is living alone and is still on clobetasol propionate therapy. The physical examination of the patient showed excoriation and lichenification on the scalp. The neurological examination was unremarkable. Hemogram and biochemistry parameters were within normal limits. Magnetic resonance imaging was normal. The patient's self-care was decreased. Speech content was impoverished. Stereotypes were available. The patient's answers to the questions were irrelevant, his mood was dysphoric, affect was inappropriate and his mind was impoverished. No pathological finding was detected in perception. The patient was diagnosed with delusional disorder and was started on risperidone longacting injection $37.5 \mathrm{mg}$, once in 15 days, because it was thought to be incompatible with oral therapy. After a follow-up in consultation with the dermatologist, the patient's complaints were controlled within a month, and subsequent follow-ups and treatment were continued through home care services. At the end of the three-month follow-up, no similar symptoms were reported.

\section{Discussion}

The most important step in the treatment is to build confidence in the patient-physician relationship. For adequate treatment of delusional parasitosis, it is necessary to differentiate between the different types (1). While antipsychotic drugs provide significant treatment in primary delusional parasitosis, they are only used symptomatically in cases secondary to somatic diseases and the treatment of the underlying disease is required. Typical antipsychotics, atypical antipsychotics, antidepressants, electroconvulsive therapy and dermatological agents can be used individually or in combination (3). In most cases of delusional parasitosis, once symptoms have settled, response to treatment is generally low. The delusional system settles and becomes chronic in patients who remain untreated for long periods of time. Suicide has also been reported as one of the outcomes (2).

In contrast to the common features of Ekbom syndrome, our case was a male patient living alone. The patient was in a vicious cycle and adherence to treatment was poor. He did not believe that his illness could have a psychiatric aspect. Since he had not been treated for many years, the disease had become chronic and various complications had arisen. Since it was thought that oral treatment would not be appropriate in such a patient, antipsychotic long-acting injection was initiated, and followup was provided through home care services. The majority of cases and studies in the literature focus on oral treatments. Traditionally, typical antipsychotic pimozide is considered as the first choice of drug, but it comes with a number of serious side effects $(5,6)$. According to Aït-Ameur et al. (7), pimozide is currently the most effective treatment. However, compliance with oral treatment is not possible in chronic patients with inadequate social support $(2,8)$. Nevertheless, antipsychotic long-acting injection also has some serious side effects-dystonia, oedema and neuroleptic malignant syndrome to name a few. In order to respond quickly to these possible side effects, a followup is recommended at short intervals (8-10).

In conclusion, this case report shows that antipsychoticlong-acting injection use is an important treatment option in patients with chronic, non-compliant Ekbom syndrome. It is recommended that clinicians keep in mind the use of antipsychotic longacting injections in this disorder, which is difficult to treat even under normal conditions. Further systematic research should be conducted with respect to antipsychotic long-acting injection use in Ekbom syndrome to provide a greater understanding of both its prevalence and aetiology.

\section{Ethics}

Peer-review: Externally peer reviewed. 


\section{Authorship Contributions}

Concept: E.Ç., M.H.Ö., Design: E.Ç., M.H.Ö., Data Collection or Processing: E.Ç., M.H.Ö., Analysis or Interpretation: E.Ç., M.H.Ö., Literature Search: E.Ç., M.H.Ö., Writing: E.Ç., M.H.Ö.

Conflict of Interest: No conflict of interest was declared by the authors.

Financial Disclosure: The authors declared that this study received no financial support.

\section{References}

1. Mumcuoglu KY, Leibovici V, Reuveni I, Bonne O. Delusional parasitosis: Diagnosis and treatment. Isr Med Assoc J 2018;20:45660.

2. Karakus G. Delusional parasitosis: Clinical features, diagnosis and treatment. Current Approaches in Psychiatry 2010;2:384-400.

3. Campbell EH, Elston DM, Hawthorne JD, Beckert DR. Diagnosis and management of delusional parasitosis. J Am Acad Dermatol 2019;80:1428-34.
4. American Psychiatric Association. Diagnostic and statistical manual of mental disorders (5th ed). Washington, DC: 2013.

5. Barone Y, Niolu C, Zanasi M, Siracusano A. Ekbom syndrome treated with olanzapine: a case report Sindrome di Ekbom trattata con olanzapina: un caso clinic. Journal of Psychopathology 2014;20:66-8.

6. Orum $\mathrm{MH}$, Egilmez OB. Compulsive water drinking resulting in hyponatremia: A pimozide case. Med Records 2019;1:48-9.

7. Aït-Ameur A, Bern P, Firoloni MP, Menecier P. Delusional parasitosis or Ekbom's syndrome. Rev Med Interne 2000;21:182-6.

8. Örüm MH, Kara MZ. Zuklopentiksol dekanoat uzun etkili depo enjeksiyon kullanımına bağlı yüz ve periferik ödem: Bir olgu sunumu. Med J West Black Sea 2019;3:26-9.

9. Orum MH, Yilmaz H, Bildik T, Kara MZ, Gonul AS, Erermis S, et al. Differential diagnosis of a patient with psychotic disorder with high creatine kinase and subfebrile fever: A case report. Azerbaijan Medical Association Journal 2017;2:23-6.

10. Ceylan MF, Erdogan B, Tural Hesapcioglu S, Cop E. Effectiveness, adverse effects and drug compliance of long-acting injectable risperidone in children and adolescents. Clin Drug Investig 2017;37:947-56. 